\title{
The region as an object of projecting of neo-spheric existence in the depth of anthroposphere
}

\author{
Anatoly Samodryn ${ }^{1}$, Lina Rybalko ${ }^{2}$, Olena Lavrentieva ${ }^{3,4}$, Walery Zukow ${ }^{5}$, and Ali Emre Sarılgan ${ }^{6}$ \\ ${ }^{1}$ International Humanitarian and Pedagogical Institute Beit-Chana, Department of Pedagogy and Psychology, 3 Uspenska Sq., Dnipro, \\ 49000, Ukraine \\ ${ }^{2}$ National University «Yuri Kondratyuk Poltava Polytechnic», Department of Physical Culture and Sports, 24 Pervomaiskyi Ave., \\ Poltava, 36000, Ukraine \\ ${ }^{3}$ Alfred Nobel University, Department of Innovative Technologies in Pedagogy, Psychology and Social Work, 18 Sicheslavska \\ Naberezhna, Dnipro, 49000, Ukraine \\ ${ }^{4}$ Kryvyi Rih State Pedagogical University, 54 Gagarin Ave., Kryvyi Rih, 50086, Ukraine \\ ${ }^{5}$ Nicolaus Copernicus University, Department of Spatial Management and Tourism, 1 Lwowska Str., 87-100 Torun, Poland \\ ${ }^{6}$ Eskişehir Technical University, Department of Aviation Management, 2 Eylül Kampüsü Str., Tepebaşı, Eskişehir, 26555, Turkey
}

\begin{abstract}
The article deals with the problem of the modern education system perfection and at the same time seeks to reach the limit of the possible in the transformation of the educational space to meet the demand of time, its ability to provide social consciousness in the conditions of the ongoing crisis and those changes that caused the intensification of the dialogue between Man and Nature. The development with the participation of humans becomes of a more targeted nature - noospheric and educational, global one. This is a new way obliges a modern general education institution to look for better approaches to the production of personality and promote the development of modern man - the carrier of new values. The state of society's consciousness should be inclined to act in the direction of its spirituality. The correlation between the social and morphological organization of a human being should not be beyond the problem of profile education. he human world to a large extent begins in a human being itself, therefore, the objective of this article is the search for ways to change the educational system of the region for the sake of further formation and development of the democratic society of the anthropospheric era.
\end{abstract}

\section{Introduction}

In the 21st-century mankind is rapidly turned into the active creator of the world due to their appropriately educated intelligence, as ideally, all people of the planet are dimensions, connected by education and mediated by God whose means the Word. The main issue for the contemporary school system is to retrieve this "correct" rule of education for the contemporary person.

At this time, all occurrences of our life can be dealt with success only via an empirical way of perception, but not hypothesizes into account. Only by doing so, we are able to introduce new opportunities, new principles, and axioms into science, according to the opinion of Vladimir I. Vernadsky (from Diaries, May 1921) [1]. At this moment we are approaching the stage of our development, whos has already been reached by the genius persona of Vladimir I. Vernadsky. Scientist left us an all-pervasive sign of the guidance of his supreme intelligence: life is omnipresent and ceaseless in time, the mineral essence of the world stems from the aspect of life itself and the geological role of the person in particular and humanity in general. This stage is a shift from the biosphere to anthroposphere and explosion-like viral spreading of scientific awareness. Meanwhile, the organization of science is the anthropospheric feature, provided by the appropriate education [2] .

The research is the empirical summarization of the issues of the current time and is the complex hypothesis with the outlined attitudinal guiding lines, which interprets the tendencies of development of the contemporary educational system, that urgently and spatially requires the appearance of essential basic points of life projecting, based on the incomplete theory of the region of the biosphere.

It is worth noting, that the term "region" is common in many languages. Predominantly it is prone to reflective modelling of some imaginable locations on some territory and is more frequently used in the sphere of administrating or economics where it introduced as the separate dimension. In Ukraine there was a politically active "Party of the regions", but their policy has nothing to do with everything highlighted in this paper.

The goal of this paper is search of ways the improve the educational mechanism of formation of the personal potential, aimed for the successful and efficient changes of the educational system of the region of the biosphere for the sake of further formation and development of the democratic society in anthropospheric era.

\footnotetext{
${ }^{*}$ Corresponding author: helav68@gmail.com
} 


\section{Materials and methods}

In 2018, the Club of Rome for its half-century anniversary prepared a report "Come On! Capitalism, myopia, population and the destruction of the planet". The report, at first sight, was in line with the ideas of Vladimir I. Vernadsky, but in view of a probable procedure, its solution did not correspond to the humanist scientist's plans who upheld the triumph of the individual in the biosphere and believed in the possibility of scientific piloting of the biosphere.

The co-author of the report "Come On! ..." was Elvir Weizsäcker, who emphasized follow: "In the heart in our main idea is the difference between an empty world and a full one. In the period of the "empty world" mankind was small, and nature was many. This period ended in the 70s and 80s. Now we have a "full world", a huge number of people, three times more than in 1945. But the planet is not growing. This is one of the main problems that the Club talks about" [3].

His viewpoint in this issue Volodymyr I. Vernadsky expressed in 1925: such synergetic and dual entity surely causes the correct stream of the mind flow about making the demand for a decent education, "causes the element of creativity, which will engage the capital of knowledge, and ability to retrieve the necessary elements even from the strangest and the most unknown creatures for some person" [2, p. 125].

Therefore, in this study, it will have used follow methods such as theoretical analysis and generalization of worldviews of Vladimir I. Vernadsky [1], Lev N. Gumilev [4], Olexandr P. Kovalyov [5], Yuriy M. Lotman [6], Frederick Schelling [7], Oswald Spengler [8]; correlation and comparison of the theory of the biosphere region, the theory of the biosphere of Vladimir I. Vernadsky and the theory of the noosphere by Pierre Teilhard de Chardin [9]; as well as observation and modelling. These problems were comprehended and considered in publications of Vlail P. Kaznacheev [10], Olena O. Lavrentieva [11], Lina M. Rybalko, Oleh M. Topuzov [12], Anatoly Samondrin [13] and others.

The presented research is an empirical generalization of the issues of modern times in the design of the neosphere existence of the biosphere and outlines the trajectory of the formation of personal educational potential in modern educational institutions.

\section{Theoretical background}

The term "region" (de. Gebiet and Region f; lat. regio kingdom, domain) - in the past was the name of the land, area, county, etc and nowadays this term denotes the big territorial unit, and in physical geography, it stands for the general name of the unit, which is the part of the physical and geographical division of any taxonomic rank, and in historiography, it means the historical and geographical region, as well as the name "economical region" used for economical for studies. Methodologists emphasize the validity of the geographical theory of regional development. The scientific perception of this definition remains unclear, especially concerning the pedagogical aspect, which has always been the supplementary element of social and economic development, but, unfortunately, not the core of projecting [13].

There are qualities that are taking place as factors defining the region as a complex social system. They cover the relative apartness, integrity, complexity, structurdness, the subordination of the single objective to ties with the external factors.

The term "region" was quite thoroughly explored by a Ukrainian scientist Olexandr P. Kovalyov. He made the following statement, that defines his biospheric essence comparing to others, examined by other researchers, namely: relatively closed territorial, non-state, sociallyproductive formation, that is characterised by the relative autonomy and capability of self-reproduction of sociallyproductive functions and that phenomena, what has the appropriate infrastructure and integrated into the functional structure of cosmobiotic geospacer [5].

In contemporary economical science, the classification of Ukrainian regions provides the following categories: problematic, underdeveloped, recessionary, and depressive ones. These terms are generally and contextually similar, but also bear several differences. The issue of clear classification of regions is very actual in a whole for the elaboration of the strategy of territorial development as well as for the construction of the model of educationally-studying space of a region.

On the current level of development of Ukraine, along with the central organs of administration, the local organs are engaged in more and more activities for the solution of the problems of economic and social development of the regions, for the implementation of modern mechanisms of their support. Primarily they are used for helping "depressive" and "recessionary" territories within the scope of the goals of sustainable development. Conditionally, the monitoring of the territory of the region can be performed by introduction of several indicators, which, depending on the variety of properties, will gain a certain level of "problematic", "underdeveloped", "recessionary" or "depressive" level [13]. We are going to clarify the general characteristics of their basic properties (see Fig. 1).

The underdeveloped region is that one, whose rates cannot keep up with the average state rates, more than one third.

The problematic region should be considered such one that retains the situation requiring the supplementary (usually external) aid for its solution. They can be the ecological conditions, proximity to the border, the availability of conflict occurrences, etc.

The recessionary region must be called such one in the case of the probability of irreversible tendencies to recession of production there, the increase of unemployment, the decrease of life standards, the deterioration of health conditions, the decrease of the index of life duration.

Recessionary territory, whose recessionary state is retained for a long time, must be classified as a depressive one. Depressive territory cannot overbear the crisis without external aid. Such territory might be switched to the steady development stage only in the case of obtaining complex support and the accumulation of all resources 
(internal aid and the external one, gained from the greater organization, area or state).

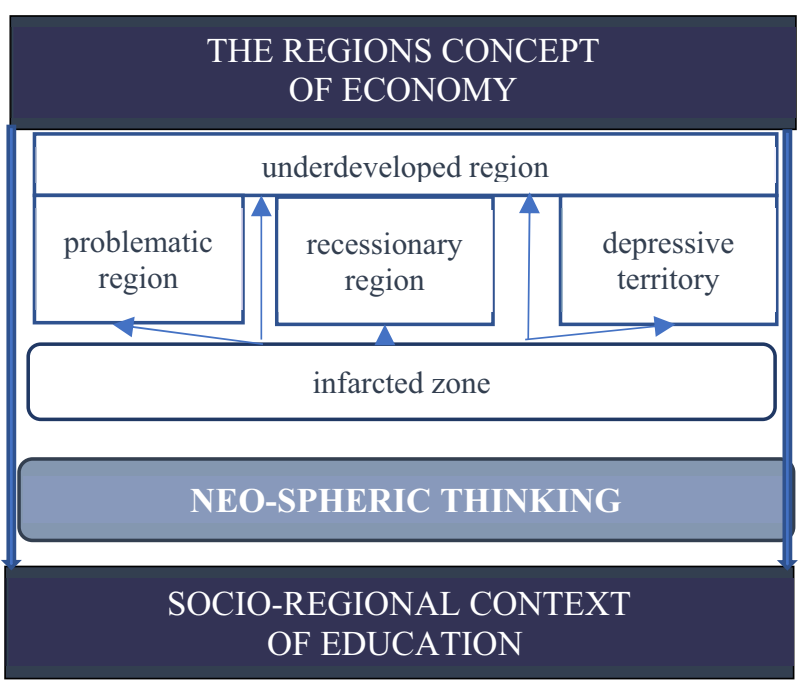

Fig. 1. The transformation of the regional concept in the sustainable development era.

It's worth noting, that recessionary and depressive territories can be part of relatively prosperous regions. Besides, the level of "underdeveloped", "problematic", "recessionary" and "depressive" levels of classification can be differentiated for various particular zones (Carpathian region, Donbas region, and Chornobyl region, etc).

One can freely state that today, the significant levers, improving the lives of the regions, are not the major driving elements of society namely education and science. Practice demonstrates the weak engagement of economical and administrative aid for the respective educationally-scientific base. Governing body of the regions regard the economy of education exclusively as the "provision of educational services for some amount of money" [5].

Moreover, all territories require individual approach and construction of certain strategy as a programme of development for a future prospect, bearing the internal nonlinear dynamics. There is a particular part of territories in the region, which are characterised by the complexity of administrative management, when a metropolis lies within the range of several administrative provinces, interacts with the territories of several agricultural districts (city-states), etc. The cultural development of the population from such regions becomes deformed. The contemporary village blindly and mechanically "delivers" its capital of labour force to the bordering country, another administrative province, single-handedly approaching its own demise. In this case, the problem of reforming borders or appropriate coordination policy of the range of regions arises.

As a rule, depressive and recessionary territories are situated near (or right in) the zones of ecological disaster, whose management requires the different quality and concentration of administrative decisions, aimed at preserving and replenishment of natural resources. The interaction between metropolis (a city or a system of cities) and polis (city-states e.g., settlements or villages) is remarked by the availability of "infarcted zone" spreading from the centre of a metropolis in a concentrated way (pollution of the atmosphere, subsoil waters and poisonous leakages of technical fabrication). Relating to the agricultural sector it can be presented as the phenomenon "on the brink" [10]. Usually, it is a certain segment that bears its own dynamics of development. This exact territory requires the most scrupulous attention during the process of estimation, carried out by specialists, and the real state of this territory and the estimation of this state create the largest disproportions of the estimation of development of the certain region, impacts on compensatory factors and, subsequently, on the level of improvement of living standards.

Today such "infarcted" territory exists in the country, although, it lies out of the rules of the estimation, made for assessment of regional development. The scientific and educational capital of the country must be focused primarily on the support of such territories for the solution to the problems of sustainable development.

It should be noted, a modern person does not control the biosphere, they only participate in its evolution, which means that they evolve as a part of the biospheric system. The scientific approach as a natural feature fundamentally changes the energetics of the planet. This stream of energy has its own velocity, which is provided by the educational system as a primary source. Anthroposhere is active in real-time and it is not the sphere of technologies, people or society. It is the sphere of intelligence as an evolutionary process in the biosphere, that is ongoing by human influence within some region. That is why the biospheric region itself becomes the basis and the beginning of certain anthroposheric educational channels.

Further, it will have considered the possibilities of socio-regional design of educational systems for the implementation of sustainable development goals.

\section{The main directions of creating educational systems of anthropospheric type}

\subsection{Education as an anthroposhere phenomenon}

Anthroposhere is the seizing of the biosphere by human intelligence with the purpose of provision of the constant development of ecumene. It is the last stage of the numerous ones of the evolution of the biosphere in geological history is the contemporary stage. It is the sphere of the interaction of society and nature, where intelligent and aware human activity becomes the crucial factor of development. It is the process, where anthropotisation is transformed into anthropologisation, within the whole planet. Anthroposhere is also the sphere of intelligence as the evolving process in the biosphere, that is performed personally in some particular region (it shown at Fig. 2).

The education of the era of anthroposphere must be anthroposophical. Anthropospheric education is aimed at the creation of the general synthesis of the human spirit, 
the inclusion of human consciousness and human activity into the global Universum, the formation of the inner world of personality, of mental freedom for realisation and mental responsibility for their doings. By means of it, science transforms from the tool of the technical progress into the natural element of social and cultural development, that features not only the human attitude towards nature but also the attitude of the personality towards other people and themselves [13]. It is also a particular programme that centrally the emphasised objective is society's development. In this way, the educational system becomes the completed mindset, which is capable to provide both the appropriate ecological awareness and mental part at the same time and consequently forms personality's anthropospheric mindset.

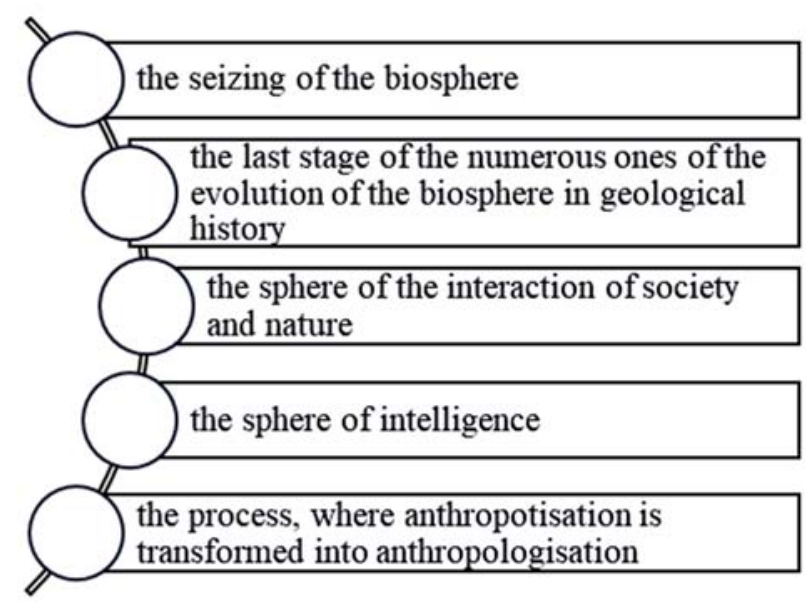

Fig. 2. The concept of Anthroposhere.

Anthropospheric the educational process is multivectored; at the same time, it is the multi-levelled system due to its naturally open and organised methods of setting objectives. It is included in anthropospheric culture and based on the principles of the creative evolution of personality. It is the profile education that is the channel of the anthroposheric educational system, that outlines the path of the evolution of Intelligence against the background of Space, the object, that it be defined as the "true person". In heart of this education is an idea that means a person is a central object of the study of anthroposphere [14].

The significant social request to the educational system during the period of anthroposphere is the organisation of the regular school, which would not only be focused on obtaining some extent of knowledge by pupils in the course of the educational and disciplinary process but also on personality's development (the role of this process is defined as the leading one, whereas any other co-occurring processes have to be perceived exclusively as the supplementary ones) and additionally on their capability of vital creativity in the World. In fact, the educational system has to clearly restate the answer to every individual "What is a person?" [13].

We know that socialisation is, primarily, the transformation of the personal one into the general one, which is also am "impersonal one" and a "commonly neglected one". Socialisation is a bilateral process, as it not only includes the assumption of social experience, but also the personal realisation of social ties by a person. Their sociological essence is focused on the combination of the adaptive and separative images, that leads to the preserving of a person's autonomy in the environment of a certain society. On the stage of reforming by society, the personality can lose their uniqueness [12]. The schools of the 21 st century mechanically perform such activity, mainly because of the principle of the "pedagogical conveyor", but due to the resistance of the personality, combine the method of socialisation, (the habitual method of industrialisation era) with the neoteric method of sociamisation (the natural process of the rise of the anthropospheric era, whose fast implementation happens because of the rapid integration of the achievements of the IT industry in people's lives), which is the process and the result of the formation of active and creative personality in combination with their equal and full-fledged integration to the society, as the unity of the citizens respecting the democratically adopted regulations and rules of the life. Sociomisation of graduates includes the fulfilment of values such as integrated ecological thinking, general liability, sense of justice, spirituality and cultural abundance, independence, initiativity, adaptive capability and readiness to manifest mobility on the labour market with the help of one's secondary education. Together with the obtained speciality and level of training added to the previous requirements, the ultimate result of sociomisation will be the "life competence" of a person [14].

The pedagogical science of the $21^{\text {st }}$-century states, the profile training (it usually includes a naturally-scientific basis, rests upon the leading type of person's activity, as well as the level of their cognitive development, polyvariety of the studying process, etc) is the basis of sociomisation and is also the best way of the realisation of the principles of differentiation and individualisation of the educational process, which is capable to embrace the issue of the development of particular personality with the help of integrative education in conditions of the contemporary development of civilization [11].

Presumably, it must be defined that educational profile is the synthesis of conceptions "en face" (fr. en face - with one's face forward) and "profile" (fr. profil, which stems from Latin - filum - "string" and "side view") is quite complex pedagogical construction, which provides for the organization of democratically basis for development of the educational content, centralised and decentralised management of the educational system, educational institution, some particular kind of organisation of didactic entities, the corresponding pedagogical culture. It represents the certain technology of assistance for mental training. The profile can be found in the personality, who explores themselves with the help of the educational system [15].

The technology of organising profile training as a process is quite scientifically-based and requires significant intellectual resources of the educational system for its implementation. As a result, the principle that has proven to be the most adaptive in this situation on all levels of management is a static principle (or the principle of template) for the organisation, which is 
focused on internal regulation, accordance, and interaction of the entity parts, and is caused by its structure and objectives as a part of educational material as the steady and invariable basis. It can be called a "paper specialisation". At the same time there is necessary organising as an ongoing process - the accumulation of deliberate actions, that stipulate the creation of indispensable ties "inside the personality" and on the way of their development, where there is a valid principle of pedagogical organization of the biosphere region as the organization of types of education, the formation of real profiles (the offers) for the real trajectories of personality's development (i.e., the personal demand).

In fact, from the beginning, any child's development must be regarded as a complex process, which is additionally optimised by a propaedeutic function of their own origin, as well as that one from the community or some social groups. What is more, the child must be correctly "placed" in the technological sense of this word. This targeted continuum of their destination must be described as "Self-concepts" in its epicentre, and "I in the segment of Space" is about their closest social partners the family, the native school, and the agency of psychological aid agency [13].

The active segment of the trajectory of the ceaseless education, where the speciality-focused approach is realising, is a regular school (educative and preprofessional type) and a higher (speciality-based) school. In light of this opinion, the pedagogical science ideally shaped approaches to the formation of personality within the scope of their genetic origin, as well as examined the objectives of the preparation of the person for the social life as a creative personality, who is fully aware of the meaning of their own life and adequately realise their intentions in some particular field of professional activity. However, the most progressive pedagogical technologies, which rely on the theory of development, are poorly studied by the total pedagogical community and can occasionally be disharmonised with their definitions, and therefore, they may be problematic for frequent usage. But only they explored the concept of personality and the pedagogical steps in a thorough way and deserve being common. This occurrence encourages further modernizing changes to the educational system (including the postgraduate one) $[8 ; 13]$.

It should be emphasized, the necessity of searching activity, self-identification, the awareness of one's own social prospects are the important needs of the young person and the tasks of implementation of the system of profile training as the structural and dynamic organisation of cooperation between personalities. At the same time, such organization requires a much broader vision of the school along with the integration of the social and psychological basis of management as the social-andecological-and-pedagogical system of the biospheric region.

Such synergetic and dual phenomenal occurrence surely causes the correct stream of the mind flow about making the demand for a decent education, "causes the element of creativity, which will engage the capital of knowledge, and ability to retrieve the necessary elements even from the strangest and the most unknown creatures for some person" as Vladimir I. Vernadsky said in 1925 [1].

Authors agree with the scientist about the understanding of democracy as a social organization of the popular rule, whose main objective is to increase the level of knowledge of the popular masses, according to the requirements of some particular period, and share scientists' views of the main educational tasks. The leading of them is to create "the studying populace", which has to be done immediately, right on this stage of the development of the educational system that is projected during the conditions of biospheric cells. Otherwise, due to the interaction of the generations, different by age, significant internal resistance is likely to occur [16].

\subsection{Features of the socio-regional aspect of education}

Nowadays is the time of born the biospheric regionology. As it can be clearly seen, that the viability of the region is tightly dependent on the knowledge of regional information and the ability to apply it in the course of the process of regional management. Let us look at the experience of Switzerland, the USA, Sweden, Germany from this viewpoint [13].

In Switzerland, the educational and scientific spheres are highly prioritised. The country, where the total population barely reaches 7.5 million people, there are 1.1 million school children and students. With its 26 cantons united (cantons, are basically, "mini-states" or regions of the biosphere) Switzerland became the place of the fusion of three major cultural and linguistic traditions - German, French and Italian ones. Approximately $65 \%$ of the population speaks German language, French is spoken by $19 \%$ of people and Italian speakers are estimated to be $12 \%$ of the total population. However, Swiss people can never be called separated because of their multilingual cultural feature. In the 19th century, the compulsory secondary education was introduced as the "greatly important social task of the decent guidance of new generations" and all cantons adopted their own educational legislation, whose basic regulations are preserved until now. That is the reasons why Switzerland has 26 cantonal "educational systems" [13].

The USA does not have any standardised educational system. Each of the states has its own particular organization of the educational system and their own special aspects, that is why the main trait of the educational system in this country is decentralization [17].

The remarkable property of the educational system of Sweden is a democratic approach, which is all about the development of the new generation as modern Europeans. The democratic character of the educational system in Sweden is manifested with the freedom of choice on all levels of education without exceptions and the fact that any pupil is free to choose not only the subjects, that they want to study, but also the study modes, the language of studying (Swedish or English) and even a teacher. The Swedish legislation clearly defines the regulations concerning the teachers' behaviour and the forms of 
teaching, which means that teacher must not impose their opinion on the pupil or perform any kind of pressure on them. A teacher must only share their knowledge with their pupils and provoke their need and abilities of independent thinking and description of their vision of the verity [17].

The sphere of the culture and education in Germany belongs to the jurisdiction of the lands (there are 16 of them in total in the country), that is why the conditions and the programmes of studying in different lands can differ one from another. Germany possesses not only the framed Law of the education but also has 16 educational constitutions, which uniquely characterise each of their lands [17].

The issues of the educational system belong to the competency of the special organ - the Constant conference of the ministers of the culture of the lands. The mentioned organ inspects the quality of the educational system all over the country in order to maintain it on a decent level.

Ukraine is also on its own way to the differentiated educational system, because of its multiculturalism and historical regional originality. Nowadays the new form of the reflection of objective reality becomes more distinctive and particularly, social and regional one with its possibility of informational reflection and creation informational and social polygons for performing different kinds of social experiments as social projecting, making the new models of development of reality and a possibility to control it. Informational regionology provides for the creation of the common informational space of the objects of the research - the region, that realises the informational reflection of social space with its all ties within the scope of the biosphere [13].

In that way, the region is regarded as the social system with its all incoming and outcoming features, functions, that provide its viability. The informational regionology provides for the solution of problems of the region with the usage of informational technologies as a system of methods of collection, accumulation, storage, search, transmitting and processing of the information with the relying on the usage of IT means. It allows the creation of the united automatized informational system, the united IRC (informational resourcing centre) for the solution of regional problems [19]. Moreover, the informational system, reflecting the social space of the region, additionally becomes the educational polygon of the social projecting and construction of the models of management is based on such projecting. The elaboration of the mechanisms of the realization of projects and discovering the tendencies of the regional development as a part of the biosphere and as a neighbour of other regions.

For the educational study, the region is represented as an integrated, spatially-organised form of the vital function of society as a system. This process is a sophisticated and complex entity and a segment of the life sphere (biosphere). Such kind of form has its own content. The regional content of education cover parts, that presented at Fig. 3.

For this reason, the simple upgrade of educational programmes in this sphere will not lead to manageable anthroposhere. It is vital to assure the appearance of the conditions when the population can unanimously be on the stage of studying. This issue is based on anthroposheric mindset and provides for the following primary steps for construction of the educational system within the certain region for getting the result of appearing of profile education:

- it is the development of enlightenment - the perception, understanding and responsible attitude of the popular masses towards the ongoing events;

- it is the cultivation of the idea of the unity between the person and nature;

- it is the focus on the educational on conceiving of fundamental natural principles;

- it is the supplement the principle of anthropocentrism in the educational process by the principles of biocentrism and cosmocentrism, as well as with principle of anthropocosmism as a final result of their fusion.

THE REGIONS CONCEPT OF EDUCATION

MAIN PRINCIPLES

anthropocentrism, biocentrism, cosmocentrism

1. The interaction of subjects in the process of reproduction of conditions of vital function.

2. Physical and real factors, that are the basis of sociocultural reproduction.

3. Quantitive and qualitative indicators, that characterise the result like the level of socioeconomic development of region.

4. Functional internally-systematic ties, that outcome from the relations of possession, relations of separation of the factors of power and competences in the region.

5. A regional self-governing mechanism, whose elements are mutually dependent and intercomplementary to each other.

Fig. 3. The concept of region educational content.

\subsection{The process of regionalization in the context of the formation of educational area}

The environment, where the human is being and existing, is classified with a certain organization (it named as geographical one). It includes several special complex dynamic elements - geosystems, which create a unique space (geographical chronospace) because of their interaction. The formation of this process is tightly related to the term of "geoprocess", which denotes the process of geospatial self-organising. Exploring the geospace, a person generates its reflection in their consciousness for the regulation of their economic activity.

Economic sphere encourages people to aim their own activity at the culturally-economical evolution, which leads to the creation of regional anthroposhere, as well as the regional cell. However, this process primarily impacts on a person. It manifests the phenomenon of regionalization as a process of initiation and formation of 
anthropospheric structure. Nowadays, the point of leading the regional policy is stuck with the task of provision of educational system for some region, and with the problem of the elaboration of the best methodology. The methodology has to answer on the question how in the best way to find the fundamental points, around which will be founded on learning any particular person and population in general. Clearly, regionalisation is a process of infringement of the symmetry of geospace, which initiates its renovation and stands out as an excess of anthropotisation and raises the problem of anthropologisation [12].

On the other hand, human activity, which can be involving or not involving the energy from outside (if it is concerning several ecosystems), tends to several spatial correlations and modelling (enforcing or weakening) of some coherence. In this way, the region transforms from the socially-productive sphere (with the support from the scientific sphere) toward a socially-natural organization. Additionally, the understanding of the distinctive features of some region expects the adress of biospheric and productive pedagogics. Anthropotised territory must create separate autonomous production (autotrophy) instead of the assumption of different economies (heterotrophy) [12].

Regionalisation as a biospheric feature embraces the whole range of processes of anthropic type, which can be quite or very complex themselves because of their interaction with each other and interplay between the processes of evolution and deformation of the environment. These processes are self-organising and are carried out as an evolution of geospace. Regional infrastructure bears its own topology, which eventually evolves towards quite repetitive productive cycle. According to the result of our analysis, in the course of self-organising, geospace (besides the tendency to unite into one system), tends to autonomy and relative independence, which is represented as an objective reality. Energy, as well as the information (with the educational systems included), is the common and different feature, that the region contains.

The educational system of the region gradually reflects the whole range of cultural traditions about the interaction with other regions and subregional creations, as well as the competition with other regions for energy, raw materials, population, territory, productive, cultural functions, and whatever. It gradually evolves into the global structure of anthroposphere with the elements of complementation, cooperation, and connection with other regional structures, and is included to the cultural sphere which leads to the creation of the second nature (in this way the process of ceaseless separation of the person and nature takes place).

The production net (the labour source), which is accompanied by the appropriate education, capable to reverse the person back to their connection with nature, becomes a major correlator and determiner of the development of the region. In the course of evolution of anthropospheric educational system the biosphere region functions like a cell of nature (in other words it is harmonically), but only in the case of having the consciously intelligent completion of the connection between a person and nature, as a part of the regional educational component. Analysis of the geosphere clearly indicates that the points of growth of anthroposphere create the ethno-cultural clusters inside biosphere that provoke the huge "quality leap" - the shift from the regional humanity to self-management of biospheric regions-cells like a movement from anthropotisation toward anthropologisation of the territory. The places of the cultural gaps manifest the wholly different picture: there is a tendency to biospheric federalization and autonomisation of societies [13]. This process is shown in fig. 4.

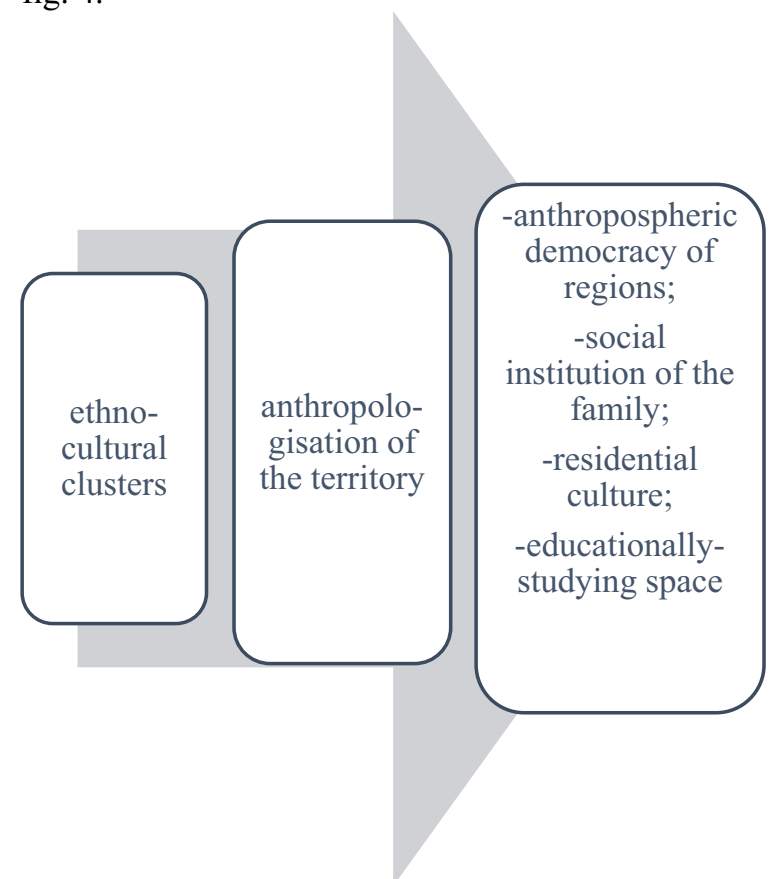

Fig. 4. Process of anthropologisation of the territory.

The particular ethnocultural "pluripotential" cluster of anthroposphere of the planet in 2019 (Top-20 countries of the world where the average life duration is 75 years for male and female population together: Japan, Singapore, Switzerland, Spain, Andorra, Australia, France, Italy, Iceland, Israel, Luxembourg, Norway, Sweden, Canada, Finland, the Netherlands, Austria, New Zealand, Malta and England (material is taken from Wikipedia). The named countries abide by the democratic mode of governing, are sufficiently wealthy with the high level of cultural development, based on the scientific, educational and religious spheres.

So, the criteria of formation of ethnocultural anthropospheric synthesis can be named as "several average durations of life, achievable for ethnocultural class", which currently is a duration of 75 years for male and female population together on the condition of democratic lifestyle. The vocation of "new paradigm" or "anthropospheric educational paradigm" being drafted to unite the world population into one entity, has not elaborated the tradition of anthropospheric democracy of regions as a culture of projecting due to the absence of methodology (authors consider this fact by). At the same time, unfortunately, some nationalities' mentality still bears the intermission, pause, some indifference, primarily caused by the change of some guidelines of 
evolution, relative to which the local educational systems are being late [13].

The most specific problem for anthropospheric educational system is the social institution of the family, which not only serves for the satisfaction of the main human instinct of preserving and reproduction of their kind as well as the tradition of the existence of the family. The institution of the family also represents the state of creative human evolution, which involves the implementation of new "anthropospheric order" in the mental atmosphere of residential culture in general, and particularly the familial orders. In this way the code of the regulations and rules insides the society will historically and democratically change in order to get the further preserving and harmonization of the social space.

As it could be seen, philosophy, science, education and religion are yet to agree on the integration of their own subcultures into the anthropospheric one as a potential of enforcement of cephalisation with the result of the creation of anthropospheric democracy.

The alternative to globalization with the creation of global monoculture (term by Vladimir I. Vernadsky) is a biospheric regionalization of ethnocultural development as a part of multicultural, interregional cooperation of educational and labour systems, is partially carried out as an ethnocultural clustering with the formation of united territorial hromadas (UTH). The next step is the formation of territorial districts or lands. However, the regional component of educational content in Ukraine is delayed in both its elaboration and implementation. Such a step would be able to relieve the tension in bordering lands like Zakarpattia, Donbas, the Crimean Peninsula, etc [19].

This statement must urge the creator of a new textbook for pupils to initiate the objective dialogue, primarily with the fundamental science, with the actuality of 25-30 years ahead in the given study material, along with the elaboration of the instruction about the application of didactic means during the pedagogical process. Without the correct objective, the educational process is focused on the study content, that is the historical trap, which cultivates civility instead of civilization, and consequently opens the way to necrosphere (term by Vlail $\mathrm{P}$. Kaznacheyev [10]), to the devastation of residential culture.

People created the culture as a "second nature" or "symbolic universe" and this way of perception presents culture as a consequence, not as a cause. Cultural baggage should be noticed, relying on the causes, which provoked its creation or formation. In this way all school subjects must be created. Terms, meanings, artefacts and cultures, uniting them are the product of human personality's activity, as a part of Vernadsky's "Live liquid" as the basic principle of the selection of educational content for the construction of pedagogical mindset [18]. The presentation of knowledge and its perception during the course of studying humanitarian subjects, in the majority of cases is being the process of "turned upside down" that is the key problem of linguodidactics.

The educational process for the upcoming new generation must be constructed substantively and the main method of studying must be the method of problematic studying. The educational process for adults must be formed according to the professional problems, and the main method of perception must be the substantive vision: concrete, critical, systematic, the vision of synergy, vision of a project and the vision of effect [17].

The humanitarian education, as a part of educational profiles, ideally must become the anthropospheric education, the one, that accompanies the development of the pupil, both synchronically and diachronically, as a state of trophism, and on the base of complementary principle.

The real criteria of success of educator of the $21^{\text {st }}$ century is not only their lesson, their subject and his authority (category, title and academic degree) but also our life, measured by human development index "HDI" (combines the indicators: gross domestic product per capita, literacy rate and life duration) as a part of the biospheric region. These indicators can be used as a proof of the pedagogical efficiency during the switch to anthropospheric pedagogics.

\subsection{Synergetics in the design of the educational process}

Considering the fact that phylogeny transforms into ontogeny not in an accidental way, but in the case of a certain amount of visible external conditions, we are likely to deal with the sufficiently imbalanced educational process, that tends to be even more imbalanced at the beginning of the $21^{\text {st }}$-century. It is in the course of a search of the model for internal restructuring and new reorganization. Hence, using the language of synergy, the task is to generate the administrative decision as to the preparation of ordering of all elements of the pedagogical system - internally-systematic moving to the goal: to generate the educationally-studying space and provide the reality of "understanding the understandable one" on the deeper level and subjectively level toward lead the studying process to the laws of informational systems.

Educationally-studying space from the synergetic point of view is a differentiated quantum (it is being in the particular state) self-regulating and open macroscopic system, subordinated to laws of development in the material world (in its whole manifestation), where the pedagogical energy is spread for harmonic construction of the image by the educational system. More exactly, it is the system of ties between the personality and the Universum, like the objective reality in time and space. The state of this system should be comprehended as a multitude of relations of independent properties, which characterise the system at some particular temporal moment [12].

The multitude of states of this system forms the space of states. The course of educationally-studying space from one state toward another (new) state is a particular trajectory of motion (a complicated attractor) in the space of states (it means states of the educational system and state of learning). The transition from one state to another one can be done in two ways: 1) the accidental transition when the term "objective" cannot be applied to such action; 2) the deliberate one when the action does with a 
concrete purpose. In the second case, the deliberate movement towards the goal is determined from outside or by the state of the internal environment of the system (the state of studying in this particular case). But the constructed system does not tolerate the imposing of external structures. During the creation of the new educational system, there is one remaining thing to do: to assume the laws, that are used for running such systems and create managing impacts, whose functional character is close to the character of the functionality of the targeted system [13].

Therefore, educational space with its internal element possesses the space of teaching, and its external element - the space of studying. Education is represented as the state of consciousness, as the measurer of information, the state of accumulation and arrangement of the information of the internal system (it is the system of teaching) and the state of connection with the general informational net (it is the current state of society of anthroposhere).

To manage educational space, one must possess the theory, which can be the base for the operation of planification and prediction of the multisided vital process. The development of personality stimulates their personal educationally-studying space to develop along, that is a balanced part between the educational space of the society and educationally-studying space of the particular region (see Fig. 5).

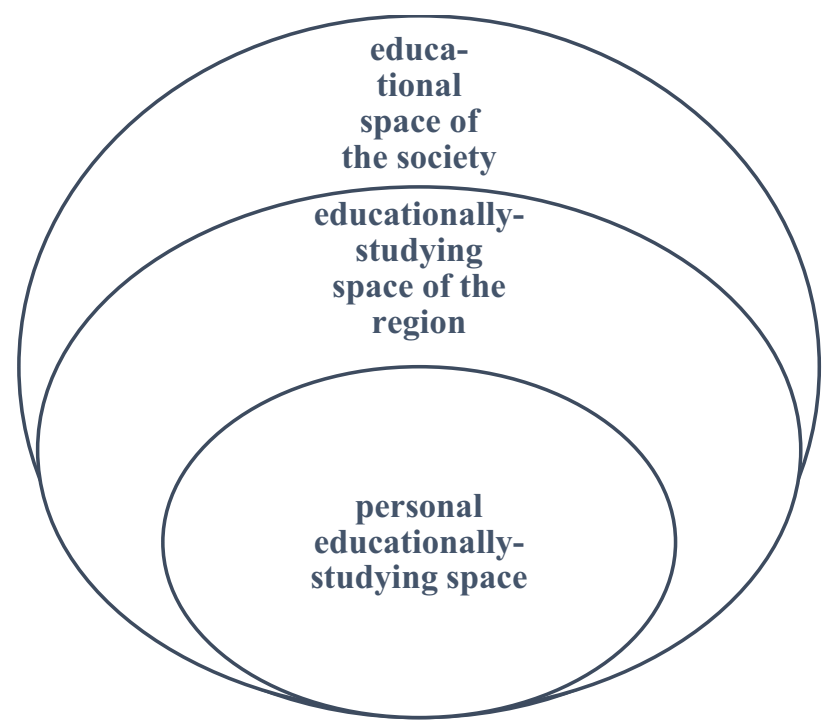

Fig. 5. The personal development space.

Thus, the personal development is realised as the intersection of the global informational net (educationally-studying space of the region) and personality's educationally-studying space [20].

Due to ordering of the person via to the sort of action, in the social cooperation will create, within quasiceaseless process, "the critical factor of potential action" - the activation of thinking and, as a result, the explosion of creativity, and finally as the stream of kindred work the innovative activity.

This process is provided by the educational system via the system of promising concepts of educating and developing of a particular individual and the society in general. The sense of life of the modern Person is their adaptation to Space with the mediation of the identification of the personal aspect into the social one, along with the creation of synthesis of public and professional mindset in conditions of vastly-growing oikumene, ruled by Intelligence.

\section{Conclusions}

Any nation possesses not only the local geographical dimension (within intersection of physical and economical geography) - as a country on the global map and a state, but also the global and spatial ones - its body, soul and spirit. Their point of intersection is an aware and reflecting person. To become a nation the nationality must assume the humaneness as a mindset and invoke their culture and mental efforts. The following ideas are included in the anthropospheric humanism of Ukraine:

1) Projecting of the future as a part of educational and ideological triad like "social state - civic society ecological mindset" must be initiated in the conditions of the educational system of the region as a completely natural territory, where the public, regional and studying components of the content of education (academic and supplemental parts) are function.

2) Educational system of the country has to be ruled by the framed law about education, as well as the regional educational specimens - the regional educational constitutions. At the same time, studying component of the educational content must be elaborated on the base of regulatory documents of the educational institution, created and coordinated by the community in a favour of some particular personality's development.

3) The educational path begins as a psychologicallypedagogical issue and the part of some personality; it lasts as the polymorphism of interests (formless one - broad one - vital one) towards the possibility of their realisation with the help of social efforts via the profile mode of educational.

4) The beginning of comprehension is cultivated by the correct immersion of personality into nature, as well as into life by means of the creation of ecological tracks with the points for contemplation and examination of an environment with the possibility of comparing the things to the ideal. This way allows to deepen of the content of educational material, realises decomposition of the problem of the life quality perfecting on the base of scientific emphasis of the method.

5) The educational environment has to develop according to democratic principles, where the atmosphere of justice is present, the balancing of all branches of government on all level of organisation is available as well as the respect towards the personality is exist.

6) Anthropospheric educational system of profile type releases the potential of the synthesis of natural and historical processes, considers the rate of formation of global democratic social relations as a combination of labour, intelligence, and scientific research, related to the religious context in favour of civilization.

7) Awareness is a result of evolution, whose origin bear genealogical character, personal embodiment and collective usage, which can be direct and indirect. A 
person's world predominantly begins inside them, is constructed by them "settles down" inside them on the final stage of its development, that is why the profile of learning must be mentioned as the duration, where the vital energy circulates.

8) The new motivating of human life as the immortality of personality, who is a part of space is necessary because the comprehension of something possible, the awareness of something necessary and scientific clarification of something conceived is one unanimous idea of the people from the planet Earth.

\section{References}

1. V. I. Vernadsky, Nachalo i vechnost' zhizni (The beginning and eternity of life) (The Sovetskay Rossia, Moskow, 1989), p. 704

2. V. I. Vernadsky, Nauchnaya mysl kak planetnoe yavlenie (Scientific thought as a planetary phenomenon) (The Science, Moskow, 1991), p. 270

3. E. Weizsaecker, A. Wijkman, Come on! Capitalism, Short-termism, Population and the Destruction of the Planet (New York, Springer, 2018), p. 220

4. L. N. Gumilev, Etnogenez i biosfera zemli (Ethnogenesis and the biosphere of the earth) (The Iris-press, Moskow, 2006), p. 557

5. A. P. Kovalev, Regionalizacziya na sovremennom etape: elementy proshlogo, nastoyashhee, budushhee (Regionalization at the present stage: elements of the past, present, and future). Regional perspectives J. 4, 6-11 (2002)

6. Yu. M. Lotman, in Stati po semiotike kultury $i$ iskusstva (Articles on the semiotics of culture and art) (The Academic, St. Petersburg, 2002), p. 543

7. F. W. J. Schelling, Die Philosophie der Mythologie, in Sammlung Metzler book series (New York, Springer, 2016), pp. 158-160

8. O. Spengler, Der Untergang des Abendlandes (Charles Francis Atkinson, Germany, 1926), p. 507

9. P. Teilhard de Chardin, Le phénomène humain, in Revue des questions scientifique. pp. 390-406 (1930)

10. V. P. Kaznacheev, Zdorove nacii, kultura, futurologiya XXI veka: Sbornik statej $i$ dokladov (Health of the nation, culture, futurology of the XXI century: Collection of articles and reports) (The Science, Moskow, 2015), p. 250

11. O. Lavrentieva, V. Pererva, O. Krupskyi, I. Britchenko, S. Shabanov, Issues of shaping the students' professional and terminological competence in science area of expertise in the sustainable development era, in ICSF (2020). DOI: https://doi.org/10.1051/e3sconf/202016610031

12. L. Rybalko, O. Topuzov, L. Velychko, Natural science education concept for sustainable development, in ICSF (2020). DOI: https://doi.org/10.1051/e3sconf/202016610030

13. A. P. Samodryn, Formuvannya navchalno-osvitnogo prostoru regionu (Formation of educational space of the region) (PP Shcherbatikh, Kremenchuk, 2006), p. 456

14. The realities of our development (Realii noosfernogo razvitiya). Collection of papers of International Conference «V. Vernadsky's doctrine on the transition of the biosphere to the noosphere and the realities of the third millennium» (Ivanovo, 21-23 may 2013), p. 396

15. V.S. Shvyrev, O deyatel'nestnom podkhode k istolkovaniyu «fenomena cheloveka» (On the activity approach to the interpretation of the "human phenomenon"). Philosophy issues. 2, 107-115 (2002).

16. N. G. Chumachenko, Regionalnoye upravleniye $i$ nauchno-tekhnicheskiy progress (Regional management and scientific and technical progress) (Naukova Dumka, Kiev, 1990), p. 158

17. O.V. Malykhin, I.G. Pavlenko, O.O. Lavrentieva, G.I. Matukova, Methods of teaching in high school: textbook (DIAIPI, Simferopol, 2011), p. 224

18. K. M. Sytnik, V.I. Vernadskiy: Zhizn i deyatelnost na Ukraine (V.I. Vernadsky: life and work in Ukraine). (Naukova Dumka, Kiev, 2010), p. 368

19. V.A. Tkachenko, O metodakh fizicheskogo opisaniya i izmereniya bioenergo informatsionnogo vozdeystviya (About methods for physical description and measurement of bioenergy information effects), in Grani poznaniya (Facets of knowledge) (Monolith, Dnipro, 2017), pp. 6-9

20. A. P. Travleyev, V. I. Vernadskiy, Ekologiya i noosferologiya (Ecology and noospherology). Bulletin of Dnipropetrovsk University. Biology. Ecology. 1-2, 12-21 (1995) 